\title{
Youth Volunteerism, as Non-formal Education, for Professional and Social Integration of Young Labor Force in Pakistan
}

\author{
Sadaf Taimur ${ }^{1} \&$ Huma Mursaleen ${ }^{1}$ \\ ${ }^{1}$ Graduate Program in Sustainability Science - Global Leadership Initiative (GPSS-GLI), University of Tokyo, \\ Kashiwa, Japan \\ Correspondence: Sadaf Taimur. Tel: 81-80-7748-0331. E-mail: sadaf.taimur@ s.k.u-tokyo.ac.jp
}

Received: July 18, 2020

Accepted: July 22, 2020

Online Published: July 31, 2020

doi:10.5539/ass.v16n8p117

URL: https://doi.org/10.5539/ass.v16n8p117

\begin{abstract}
Young people are an asset to Pakistan, and they can play a vital role in the country's social and economic development. Non-formal education to promote volunteering activity in Pakistan can endorse the professional and social integration of the young labor force by preparing them with the labor's contemporary skills. The current study is an attempt to explore the situation in Pakistan and identify: (a) if non-formal education plays a role in youth's engagement in volunteering activity; (b) why young people volunteer; (c) what they can learn through volunteering; (d) the significant barriers which can prevent them from volunteering even after getting the training and opportunities to volunteer. Data was collected using purposive sampling from 4 different nonprofit organizations (NPOs), with city offices in three major cities of Pakistan. NPOs, on their end, collected the data form the youth volunteers working with them randomly using an online survey. The research findings revealed that non-formal education plays a significant role in ensuring young people's engagement in volunteering activity. The findings and recommendations from the study can guide youth initiatives and policies in Pakistan to include systematic and consistent non-formal education programs to promote youth volunteerism in Pakistan
\end{abstract}

Keywords: Pakistan, youth, non-formal education, volunteering

\section{Introduction}

\subsection{Informal and Non-formal Education for Professional and Social Integration of Young Labor Force}

In the current era of globalization, the demand for workers with adaptive, transversal, and flexible skills have enhanced. Labor markets are looking for people who are: sociable, responsible, can work both in teams and independently, can take initiatives, and are aware of work ethics. According to Khasanzyanova (2017), Paadi (2014) and Robles (2012), those who possess these soft skills, along with technical skills, are given preference in the global job markets as compared to those who only possess technical skills. Learning is associated with the social and economic empowerment of people, to be active members of the society, therefore "individual employability potential" becomes a primary interest for learning (Duvekot et al., 2007). At the same time, integration of young people in the professional world and their transition to employment from education has become more difficult (Peugny, 2011), which can lead to the spiked unemployment rates among the young labor force. In this scenario, young people are required to equip themselves with the necessary competencies and skills to access the labor market. Engagement in extra-curricular and non-professional activities, via non-formal and informal education, can foster professional and social integration among the young labor force (Khasanzyanova 2017).

The primary importance of informal and non-formal education has been highlighted, in lifelong learning, by various organizations. European authorities defined life-long learning as" all learning activity is undertaken throughout life, to improve knowledge, skills, and competencies within a personal, civic and/or employment-related perspective" (CEDEFOP, 2009). According to Walters et al. (2014), lifelong learning is based on integrating learning and life. It incorporates learning activities for people belonging to every age, in all contexts (family, school, community, workplace, etc.) and using different mediums (formal, non-formal and informal), which together respond to a wide range of learning-related needs and demands.

The formal education, which occurs in schools, only represents a tiny component of lifelong learning (Torres, 
2011), as our schooling system still follows a uniform approach to learning, which does not give individuals the opportunities to explore and develop their soft-skills. In formal education, the curriculum incorporates technical skills, but soft skills require an additional focus to be ahead in career and life (Anthony, 2014; Wellington, 2005)

Informal education is less structured and not institutionalized. It usually takes place in communities (Singh, 2012) for example, volunteering, public libraries, community history place outside educational institutions and may comprise socially-directed or self-directed learning, or learning activities carried out at the workplace, with family members and in museums, social activism, etc. (Thompson, 2014).

On the other hand, non-formal education is an additional, alternative, or complementary to formal education within the learner's life learning pathway (Walters et al., 2014). Such as mentoring schemes, learning circles, volunteer induction, and training (Thompson, 2014). Non-formal education programs are usually flexible in terms of content and adaptability to the learners' specific needs compared to the formal programs (Walters et al., 2014), and they lie on the sidelines of out-of-school institutions (Hamadache, 1993). One of the main goals of non-formal education is to train "active citizens" and "to create and use knowledge effectively and intelligently, on a continually changing basis" in knowledge societies (EC 2000, p. 7).

According to the Council of Europe (2007), in the face of youth unemployment, non-formal and informal learning is becoming a critical activity supporting active citizenship, social inclusion, and personal fulfillment. Therefore, to be empowered and employable, it is crucial to capitalize on the competencies, skills, and attitudes acquired via formal learning in school or through informal and non-formal pathways (Duvekot et al., 2007, p. 9).

\subsection{Youth -Volunteering as Non-formal and In-formal, Lifelong, Learning}

Volunteering is one form of non-formal and in-formal, lifelong learning (Khasanzyanova, 2017). Musick and Wislon (2007, p. 3) defined volunteering as a form of altruistic behavior where the goal is to provide help to others, a group, an organization, or community at large, without expecting any material reward. According to the concepts of informal and non-formal learning, discussed above, the training and induction of volunteers fall under non-formal education, and volunteering as an activity (performed by individuals) falls under in-formal education. In other words, organizations or government bodies involved in (a) supporting volunteers (motivation, induction, training, and mobility); (b) creating more volunteer opportunities for young people; (c) raising awareness on the value of volunteering; and (d) removing barriers to make it easy for young people to volunteer, are engaging young people in non-formal education via volunteering. Young people, volunteering, on the ground (in real-life scenarios) are involved in informal learning. Volunteering not only benefits the organization or society, but it also has numerous benefits for individuals (Booth et al., 2009; Butt et al., 2015; Handy \& Brudney, 2007; Sherr, 2008). Individuals can pursue networking, career advancement, and skill development through volunteering (Casey, 2014). Other benefits include: developing a sense of achievement, confidence, and fulfillment, making new friendships, personal and religious satisfaction (Butt et al., 2015), good health (Byrd, 1984), sense of belonging (Veitch, 2013), stress management (Kim \& Morgül, 2017). The voluntary sector plays a vital role in social learning and life (Kamerāde \& Paine, 2014; Lengrand, 1982) and serves as a training ground for active living, where youth acquire skills that will be 'useful' in the workplace (Cortesero, 2013).

\subsection{Pakistan and Youth Population}

The total young population in Pakistan, between the ages of 15-24, is estimated at 36 million, and 58 million individuals are below the age of 15 . Together, they account for nearly $60 \%$ of Pakistan's total population (Yusuf, 2008). Pakistan has gone through a demographic transition, with a growing youth cluster, and this transition has opened an opportunity to invest in young people who are the next generation of workers, entrepreneurs, and parents and this investment will allow the country to grow faster by reducing poverty (Arif \& Chaudhry, 2008). The current demographic pattern makes the role of the upcoming generation very crucial. The critical element of this transition is the rise in the youth population (15-24 years old) accompanied by its rising share in the total population. According to Robalino and Cho (2012), the number of people in Pakistan entering the working-age is expanding faster than the total population. This phenomenon will likely last at least for another ten years. In Pakistan, the young labor force is expected to grow by 2.7 percent per year, with around 1.7 million young workers entering the labor market each year (Robalino \& Cho, 2012). Countries going through the demographic transition need to seize the window of opportunity before it is closed by the aging process (Arif \& Chaudhry, 2008).

Pakistan has a growing trend of youth unemployment (Qayyum \& Siddiqui, 2007). According to the World Bank' ILOSTAT database (retrieved March 2020), youth unemployment has continuously increased from $4.1 \%$ in 2014 to $7.6 \%$ in 2017 and $8.9 \%$ in 2019 (see Figure 1 - extracted from the world bank database). Youth unemployment is attributed to the malfunctioning of the educational and training system, which merely neglects 
the demands of the labor markets (Ghayur, 1989).

Pakistani youth comprises a large portion of uneducated, untrained, and unemployed young people (Soomro \& Shukui, 2015). Many young people enter the job market with no or fewer skills and, according to an estimate, more than 32\% unskilled youth in Pakistan. (Zia \& Rehman, 2011). The country lacks a literate and skilled human resource that can contribute to the development of the country. Yusuf (2008) highlighted that Pakistan has symptoms that make its youth vulnerable to radicalization; hence it is essential to bring a positive change in the environment to direct the young people in the right direction. According to (Arif \& Chaudhry, 2008), unemployment is more prevalent among educated youth in Pakistan. They face more difficulties in finding suitable jobs because of a systematic approach to review the integration of youth in the labor market in the context of the on-going demographic scenario is missing.

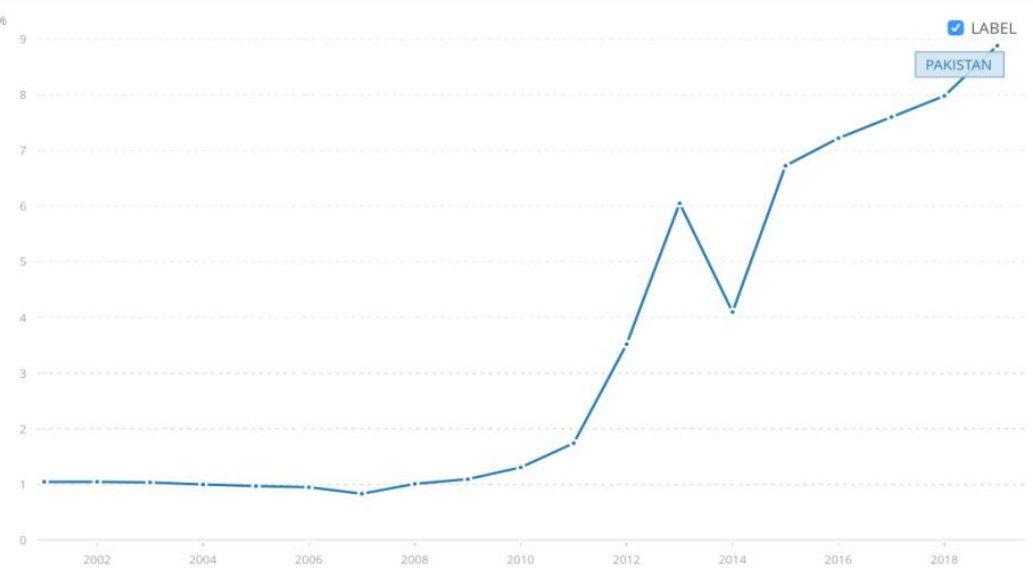

Figure 1. Unemployment, youth total (\% of total labor force ages 15-24) (modeled ILO estimate) - Pakistan

\subsection{Youth Volunteering in Pakistan}

Pakistani youth is very much energetic and ready to do something for the development of the country. Young people in Pakistan are optimistic about their role in bringing peace and prosperity in society (Basharat, 2012). Therefore, promoting youth volunteering in Pakistan can help in: (a) social and professional integration among young labor force; (b) nurturing empowered, active and responsible youth contributing to the overall development of the country. The volunteer activity in Pakistan is only $16 \%$, ranking 78th globally (Butt et al., 2015). The government of Pakistan and its institutional partners need to design such policies and programs which can prepare young volunteers and promote volunteering by providing opportunities for youth to work for the society and make a difference (Soomro \& Shukui, 2015).

\subsection{Research Purpose}

For promoting youth volunteerism as non-formal education, it is crucial to identify if non-formal education initiatives promote youth volunteers' engagement, why young people volunteer, what they can learn through volunteering and the significant barriers which can prevent them from volunteering even after getting the training and opportunities to volunteer (via non-formal education). This identification will allow the government and its partner organizations to design programs and policies which can prepare young volunteers (via training and induction), promote youth volunteering activities, and create more effective opportunities for youth volunteerism for the social and professional integration of the young labor force. The current research seeks to explore the situation in Pakistan (as a case-study) and identify: (a) if non-formal education plays a role in youth's engagement in volunteering activity; (b) why young people volunteer (motivation to volunteer); (c) what do young people think they learned from volunteering; (d) what are the difficulties that young people face during volunteering, which could potentially stop them from volunteering in the future.

\section{Method}

The study utilized purposeful sampling for data collection to achieve the research objectives. This kind of sampling is widely used to collect qualitative data to identify and select information-rich cases related to the phenomenon under study (Palinkas et al., 2015). 4 nonprofit organizations (NPOs) were identified and asked to collect data from youth volunteers, randomly, to address the questions framed for the study. The criteria for the purposeful sampling of four NPOs is as follows: (a) One of the mandates of the organization should be inducting, training and mobilizing youth as volunteers in the society; (b) Organization should be operational (have city 
offices) in at least three major cities of Pakistan, i.e., Karachi, Lahore, and Islamabad.

All 4 NPOs were asked to randomly identify young people they are working with, and ask them to fill an online, qualitative survey via Google forms (see Figure 2). This data was collected between September - November 2019 and initially, 112 responses, to the qualitative survey designed for the study, were received. But after data cleaning (where incomplete or blank responses were removed from the database), survey responses from 95 youth volunteers were analyzed for finding answers to the research questions.

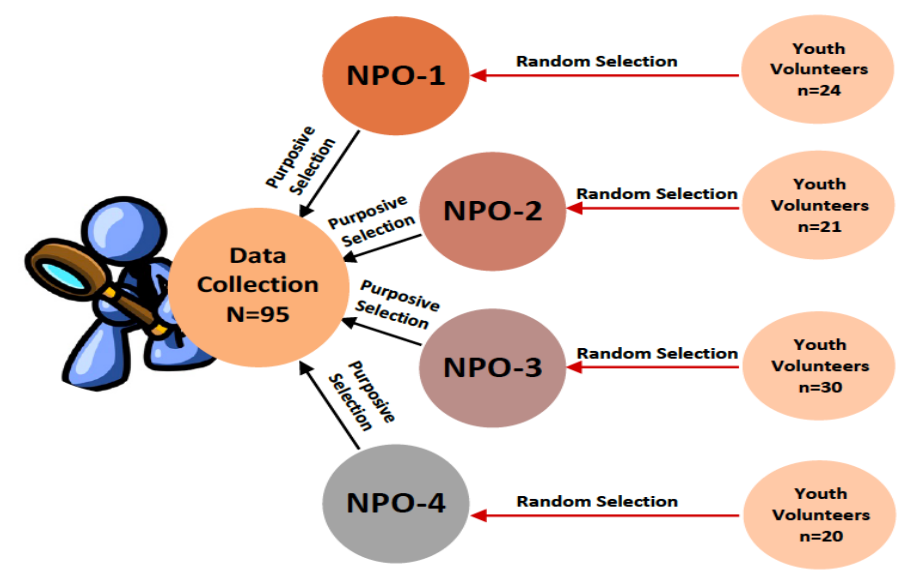

Figure 2. Experimental design for data collection

\subsection{Instrument of Study}

A survey was designed, based on the framed research questions, to identify if non-formal education initiative enhanced youth volunteers 'engagement, the motivation behind volunteering, potential barriers to volunteering, and what young people usually learn from volunteering in Pakistan. The survey also included some demographic and informative questions to collect additional data regarding youth volunteers (see Table.1). The survey was circulated among the 4 NPOs. NPOs distributed the survey, randomly, among youth volunteers working with them (in 3 different cities).

Table 1. Survey instrument of study

\begin{tabular}{|c|c|c|}
\hline . & Questions & Answers \\
\hline 1. & Age & \\
\hline 2. & Gender & $\begin{aligned} \text { Pick one: } & \\
\text { - } & \text { Male } \\
\text { - } & \text { Female } \\
\text { - } & \text { Prefer not to mention }\end{aligned}$ \\
\hline 3. & Education & $\begin{aligned} \text { Pick one: } & \\
\text { - } & \text { None } \\
\text { - } & \text { Primary } \\
\text { - } & \text { Secondary } \\
\text { - } & \text { Higher }\end{aligned}$ \\
\hline 4. & Occupation & $\begin{aligned} \text { Pick one: } & \\
\text { - } & \text { Employed } \\
\text { - } & \text { Un-Employed } \\
\text { - } & \text { Student }\end{aligned}$ \\
\hline 5 . & $\begin{array}{l}\text { Did you actually volunteer in the field after receiving the } \\
\text { training/induction and opportunity to volunteer? }\end{array}$ & \\
\hline 6. & $\begin{array}{l}\text { Where did you volunteer? Mention the organization and its area of } \\
\text { operation }\end{array}$ & \\
\hline 7. & Why did you engage in volunteering? & \\
\hline 8. & $\begin{array}{l}\text { Has the volunteering experience helped you for your career/academic } \\
\text { success? }\end{array}$ & $\begin{array}{ll}\text { Pick one: } \\
\text { - } \\
\text { - } \\
\text { - } & \text { No } \\
\text { Don't know }\end{array}$ \\
\hline 9. & Did you face any difficulties while volunteering? If yes, explain? & \\
\hline 10. & Did you learn anything new? If yes, elaborate. & \\
\hline
\end{tabular}




\section{Results}

We exported the survey data collected from the volunteers to the Microsoft excel sheets. Data for questions with the close-ended responses (mostly demographic data) were separated from the data for open-ended questions. The content of the open-ended questions was analyzed using content analysis. Content analysis is a qualitative data analysis technique, used to make valid and replicable inferences (Krippendorff, 1989). Based on the content analysis, codes were developed and allocated to relevant segments of data. The results are detailed as follows:

\subsection{Characteristics}

The demographic characteristics of youth volunteers, randomly selected for data collection by the four NPOs, are presented in Table 2. From the table, it can be seen that, for all the NPOs, the number of female volunteers is more than male volunteers. Out of 95 youth volunteers, 61 (64.2\%) volunteers are female, and 34 (35.8\%) volunteers are male. The data revealed that the minimum and maximum age of the volunteers, selected for data collection, is 17 years and 28 years, respectively.

Table 2. Demographic characteristics of the youth volunteers

\begin{tabular}{ccccc}
\hline \multirow{2}{*}{ NPO } & No. of Participants & \multicolumn{2}{c}{ Gender } & Age Range (min - max) (yrs) \\
\cline { 3 - 4 } & 24 & M & F & $19-25$ \\
2 & 21 & 9 & 15 & $19-28$ \\
3 & 30 & 8 & 13 & $17-25$ \\
4 & 20 & 11 & 19 & $18-23$ \\
Total & 95 & 6 & 14 & - \\
\hline
\end{tabular}

$97 \%$ of the volunteers reported having higher education qualifications, and only two volunteers (17 years old and 27 years old) reported having secondary school qualifications. According to the data, out of 95 youth volunteers, $57 \%$ of the youth volunteers are students, $35 \%$ are employed, and only $8 \%$ are unemployed (see Figure 3 ).

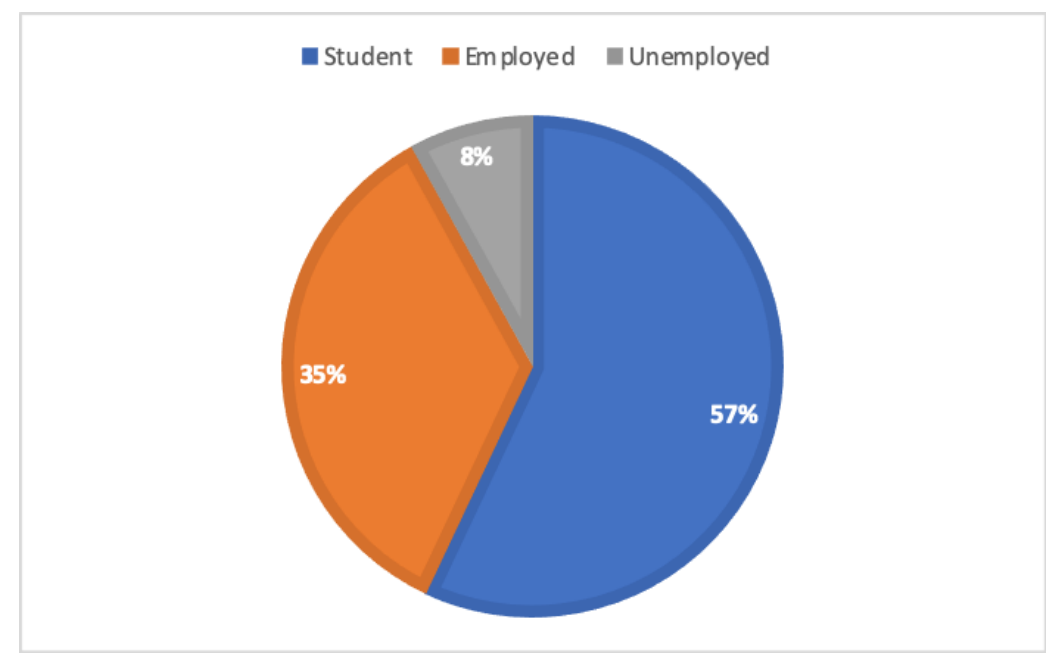

Figure 3. Occupation of youth volunteers

\subsection{Volunteering Activity}

Responses from 95 youth volunteers, selected randomly by the NPOs, were analyzed for this study. Out of 95,6 youth volunteers mentioned that they did not manage to volunteer in the field after getting the induction training by the NPOs. However, 89 individuals (93.6\%) volunteered after going through the induction training and getting the structured opportunity to volunteer. In the survey, volunteers were asked to mention the organization's name and its area of operation. Based on the responses received, 5 categories of organizations, i.e. (a) non-governmental organization (NGO); (b) government organization (Govt. Org); (c) hospitals/medical facilities; (d) non-profit organization (NPO); and (e) School/College/University, were identified. Similarly, based on the data received, 8 categories for the area of operation were classified, including arts and entertainment childcare and support, disaster relief and recovery, education and training, elderly care and support, environment, and biodiversity conservation, food and agriculture, and healthcare. 
The details of the number of youth volunteers who have volunteered in different types of organizations operating in different areas are mentioned in Figure 4. It is evident from the data that majority or youth volunteers volunteered in NGOs (33) and NPOs (30), and very few individuals volunteered in Govt Orgs (4).

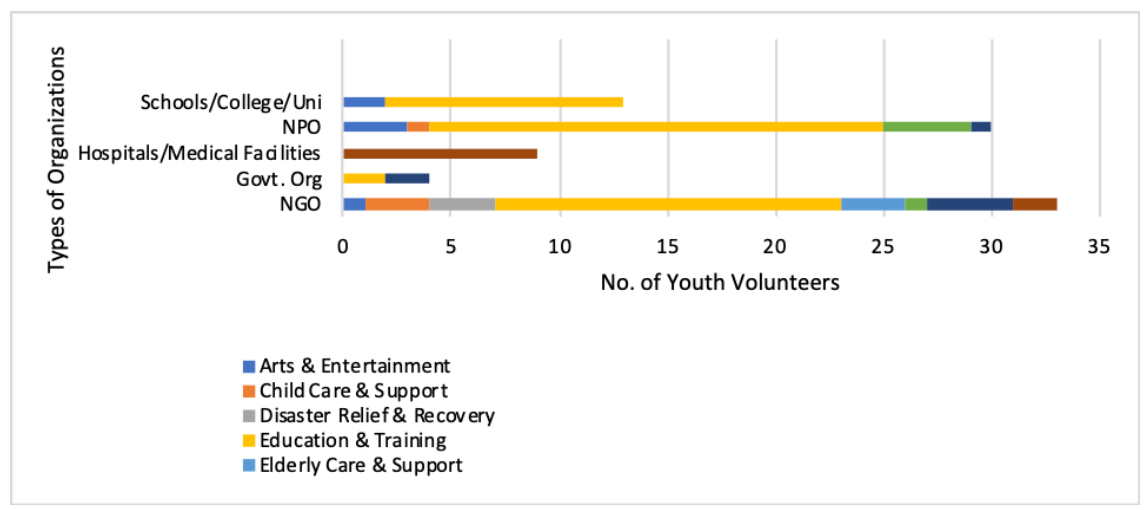

Figure 4. The number of youth volunteers who have volunteered in each type of organization operating in different areas

Out of 89 , the majority of the youth volunteers (i.e., 56\%) volunteered in the area of education and training, followed by $12 \%$ in healthcare and $8 \%$ in food and agriculture. Only $3 \%$ (each) of youth volunteers volunteered in the area of elderly care and support and disaster relief and recovery. See figure 5 for more details.

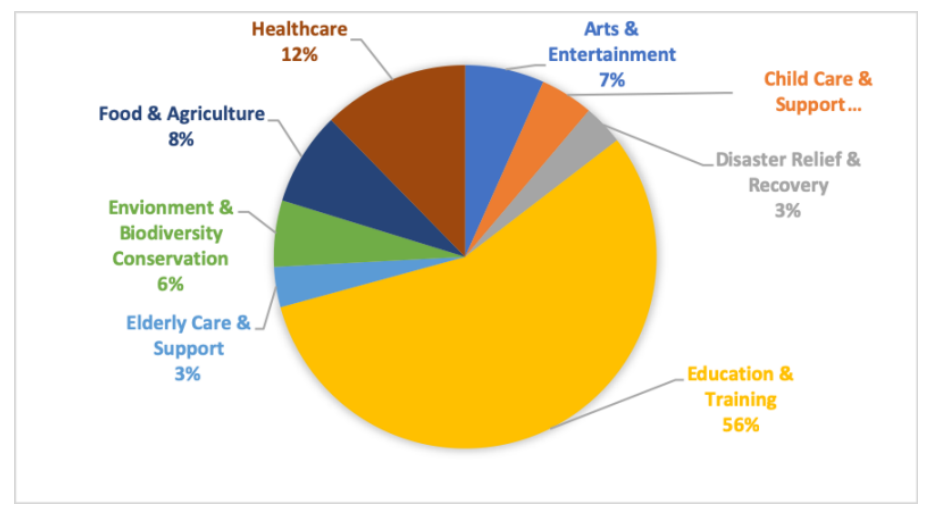

Figure 5. Percentage of youth volunteers per sector (area of operation)

\subsection{Reasons for Volunteering}

The themes that emerged from the data as to why young people engage in volunteering activity were: (a) altruism and social responsibility; (b) connection building; (c) mandatory element of the degree program; (d) self-development; (e) reward (see figure 6). Further explanation of these themes is below.

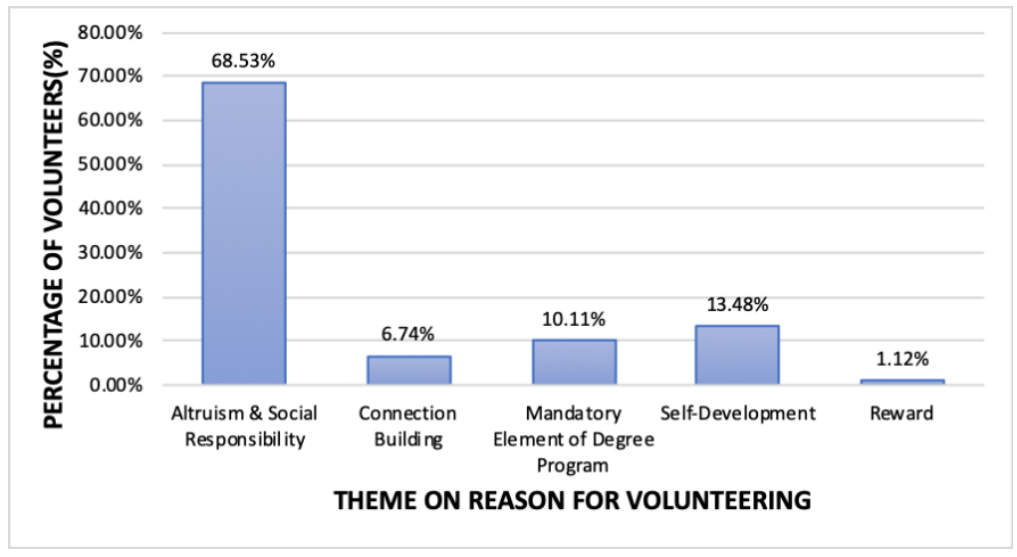

Figure 6. Percentage of volunteers per theme one reason for volunteering 


\subsubsection{Altruism and Social Responsibility}

The desire to help others in society and passion for making a difference was expressed by the majority of youth volunteers $(\mathrm{n}=61 ; 68.5 \%)$ to engage in volunteering activity. A volunteer who volunteered in an Elderly care center mentioned, "I really wanted to do something for those old people living without their families there. Helping them brought satisfaction to me."

Some volunteers regarded volunteering as a method to pay back to society:

“.....I think it is obligation upon us because we are educated and privileged. Through volunteering, we can pay back to our society. I think everyone's contribution matters in the development of nations but the contribution of educated youth means a lot" (Volunteer).

\subsubsection{Connection Building}

$6.74 \%(\mathrm{n}=6)$ of the volunteers mentioned that they want to volunteer to make connections and acquire networking skills. The connections, which volunteers wanted to build, have three dimensions. The first dimension is the connection with peers or fellow volunteers: "...I want to make friends and socialize with fellow volunteers while serving the community."(Volunteer). The second-dimension entails connection with organizations as one of the volunteers said," volunteering with different organizations will allow me build a network which will help me in future." The third dimension is the connection with the community: "I always volunteer for chores which are beneficial for the people...... this gives me an opportunity to connect with people in the community and know what they need" (Volunteer).

\subsubsection{A Mandatory Element of the Degree Program}

9 youth volunteers $(10.11 \%)$ mentioned that volunteering is a prerequisite for the degree program they are enrolled in, and therefore, they have to get involved in it. Some of them wrote that after their involvement in volunteering, they enjoyed the experience and kept volunteering in the future: "....It was a part of my Bachelors degree program...but It feels good to work for bigger causes and you get a satisfaction of helping others... I want to continue this in future" (Volunteer).

\subsubsection{Self-development}

$13.48 \%(\mathrm{n}=12)$ of the volunteers highlighted that they volunteered for self-development, e.g., gaining experience, learning new skills, or career progression. One of the volunteers mentioned that she wanted to learn new skills and gain experience by meaningfully engaging with the community through volunteering.

\subsubsection{Reward}

Only one youth volunteer mentioned reward as a reason for volunteering while saying, "I wanted to volunteer for the sake of reward and get myself recognized." However, he did not mention whether he was looking for a monetary reward or reward in the form of recognition.

\subsection{Learning}

Only 70 out of 89 volunteers $(78.6 \%)$ stated that their volunteering experience helped them in their career or academic success. Analyzing the responses regarding "if volunteers have learned anything new from the volunteering experience" led to identifying three themes: (a) soft skills; (b) technical skills; and (c) virtues (see Figure 7). The description of each theme is detailed below.

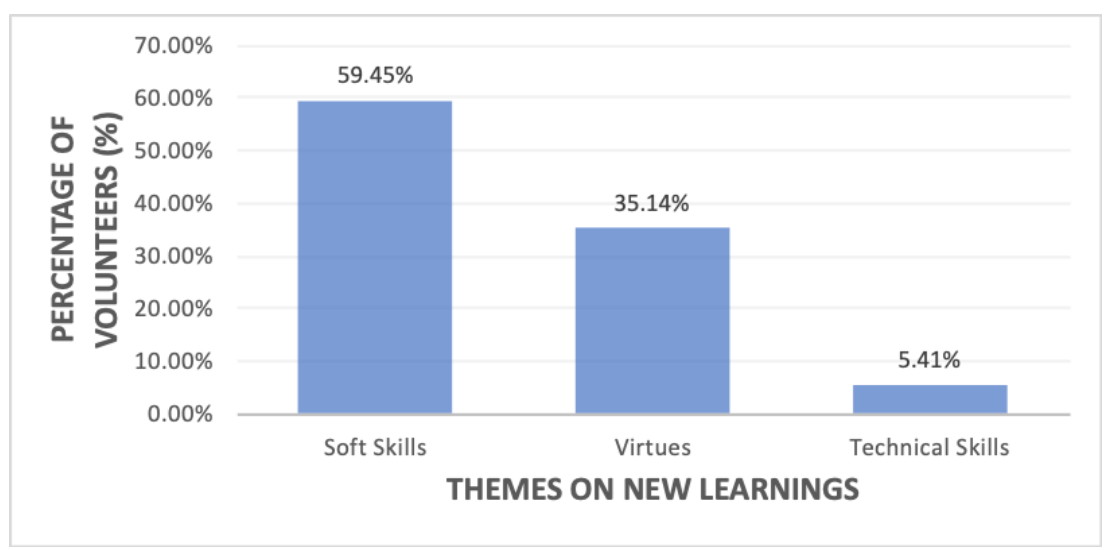

Figure 7. Percentage of volunteers per themes on new learnings 


\subsubsection{Soft Skills}

$59.45 \%(\mathrm{n}=44)$ of the youth volunteers highlighted various soft skills, which they think they have learned from the volunteering experience. Following are the soft skills along with the individual quotes from the volunteers:

- Communication skills (29.55\% ( $\mathrm{n}=13)$ of the volunteers)- "I volunteered with an educational expo, and that was good in polishing my communication skills, as I interacted with people and dealt with individuals from different fields."

- Organizational skills $(22.73 \%(\mathrm{n}=10)$ of the volunteers) - "While volunteering, I organized an educational seminar, I came to know how to organize any event, how to manage in difficult situations during the event, to overcome pressure."

- Teamwork $(20.45 \%(\mathrm{n}=9)$ of the volunteers)- "I learned many things one was that how to work in a team. We designed and worked on a training project as a team...This was a unique experience."

- Confidence $(15.91 \%(\mathrm{n}=7)$ of the volunteers) - “...I was exposed to public dealings, I think I gained confidence and now I can face people in any circumstances."

- Leadership skills (11.36\% ( $\mathrm{n}=5)$ of the volunteers) - "I learned how to lead a team more efficiently and while leading staying neutral and not making bias decisions"; “...I learned to lead and understood that my small and little contribution can bring meaningful change to someone else life."

\subsubsection{Virtues}

Young volunteers $(n=26,35.14 \%)$ also learned or polished some virtues (also known as moral excellence). Most of the volunteers mentioned that they practiced and learned empathy and compassion. A volunteer stated, “ ..... I volunteered as a nutritionist, I never knew that problems related to nutrition are so big and now I can understand the situation very well... when you can understand how people are suffering, you can work for them more effectively". Another volunteer mentioned, "...Now, I want to work to educate poor children.... It is was belief that helping people can give you peace of mind but now I have faith in it, and I will keep doing this."

\subsubsection{Technical Skills}

Only 4 volunteers $(5.41 \%)$ mentioned some technical skills, which they had learned during their volunteering experience. These skills include: writing funding proposals, typing on computers, operating different software, first-aid procedures. One of the volunteers mentioned: "I volunteered at a medical camp, and this experience taught me basic first-aid procedures...this will help me in future as well."

\subsection{Difficulties}

32 volunteers (36\%) stated that they faced difficulties while volunteering. Out of these 32, 13 were male and 19 were female. 5 themes emerged as the data, for the difficulties these youth volunteers have faced during volunteering, was analyzed. These themes are: (a) lack of impact visibility; (b) communication barriers; (c) transportation; (d) cultural barriers; (e) lack of recognition (see figure 8). The details of these themes are as follows:

\subsubsection{Lack of Impact Visibility}

9 out of 32 volunteers (28\%) highlighted that they could not see what difference their work is making and how they contribute to society. They were assigned specific tasks, but they were not shown: the holistic picture of the project they are working on and how their work fits in the comprehensive picture to make a difference: “...I have worked in an office space where I worked on some specific plans and reports... the access to information about the whole project was very limited and I was not able to figure out how am I contributing." (Volunteer)

\subsubsection{Communication}

$19 \%(\mathrm{n}=6)$ of the volunteers identified that they faced communication barriers while they were volunteering. Volunteers faced difficulty in dealing with a massive number of people at work: dealing with people at work: "It was difficult to deal with people. It gets tiring sometimes and requires a lot of energy and patience to deal with a huge group of people at the same time" (Volunteer).

Some volunteers assigned to the organizations working in rural areas had to interact with locals and found it challenging to communicate with them because they did not know their local/native language. One of the volunteers stated: "I worked to train local youth task force in a rural area and face difficulties in conveying my message.... Knowing their local/native language is very important for training purposes." 


\subsubsection{Transportation}

7 volunteers $(21.88 \%)$ identified that they faced difficulties while commuting to the workplace while volunteering. All 7 volunteers who highlighted transportation as a challenge were females, and they were more concerned about their security: "The only difficulty was of transport. I think some girls have this issue because sometimes it becomes tough to travel alone to an unknown placelor if you don't know the way to your location" (Volunteer).

\subsubsection{Cultural Barriers}

Pakistan has a male-dominated society and system, yet female volunteers are more in number. 6 Female volunteers (19\%) mentioned that they faced cultural biases and discrimination (i.e., gender discrimination) while volunteering:

"People in some organizations have an orthodox mindset and conventional approach... they consider volunteering as unpleasant for girls and that is why I faced gender discrimination while I was working as volunteer... I cannot forget when only a set segment of tasks was assigned to me as compared to my fellow (male) volunteers... who had an opportunity to work on diverse tasks" (Volunteer).

\subsubsection{Lack of Recognition}

$12 \%(\mathrm{n}=4)$ of the volunteers mentioned that, during volunteering, they dealt with a massive workload, and their work was not recognized. One of the volunteers specified, "People take volunteers for granted. I kept doing my supervisor's work, but I was never recognized even with words. People on top needed recognition for our effort and this can shatter confidence."

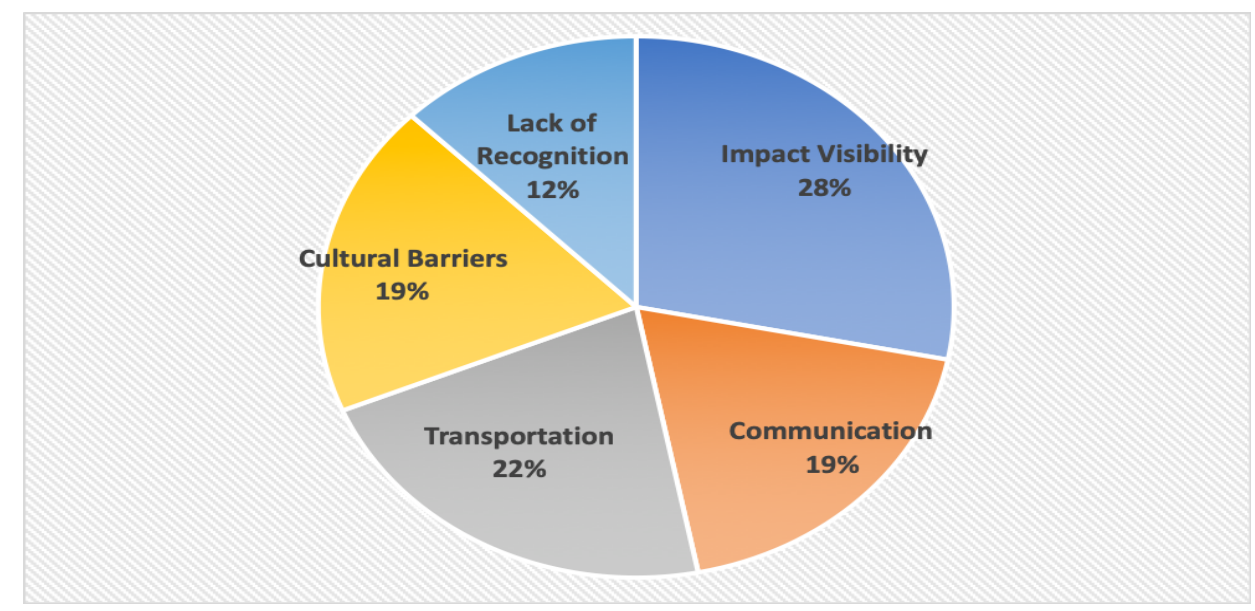

Figure 8. Percentage of volunteers per theme on difficulties faced during volunteering

\section{Discussion}

The analysis of data collected via surveys showed that the majority of the young volunteers were females $(64.2 \%)$ and had higher education qualifications. Women's participation in volunteering activity was higher as compared to men's involvement, this is also aligned to the studies conducted by Hodgkinson et al. (1992), Khasanzyanova (2017), McGarvey (2019), and Mesh et al. (2006). However, the results of our study regarding women's participation were contrary to Smith et al. (2017, p. 340), i.e., women participation in volunteering is less than men participation, in Asia, highlighting studies conducted by Lee and Moon (2011) and Srivastava et al. (2003).

Most of the young people who were trained and mobilized by the NPOs managed to volunteer and stay engaged, only 6 individuals mentioned that they did not manage to volunteer even after going through the training and getting the right opportunity. Volunteers' engagement and retention enhance with extensive use of planning, training, and support practices (Cuskelly et al., 2006; Huynh et al., 2012). Training can help individuals be active volunteers as it allows volunteers to find meaning in their tasks that will otherwise seem menial. Training also serves as a recognition to keep volunteers motivated and engaged (US Department of Health and Human Services, 2005). Therefore, non-formal education (training and mobilization) is crucial for ensuring that volunteering (informal learning) occurs.

The majority of the young people volunteered in NGOs and NPOs. Very few $(n=4)$ individuals volunteered in Government Organizations. Our study divided, volunteering activity conducted by the young volunteers into 8 areas. Our study's findings reveal that the majority of the youth volunteers volunteered in the education and 
training sector $(56 \%)$ and the healthcare sector $(12 \%)$. A study conducted on youth volunteering activity in Pakistan by Butt et al. (2015) depicted that young people are more likely to volunteer in general services (including educational, medical, and other welfare services) and religious services. The results of the current study are aligned to the first part of Butt et al. (2015) findings, i.e., more engagement in general services; however, we did not find the religious service category in our survey results.

The purpose of this research was to explore why young people in Pakistan volunteer and the significant barriers which can prevent them from volunteering or staying engaged in volunteering, even after getting the training and opportunities to volunteer. The results revealed that most of the youth $(68.5 \%)$ volunteered for altruistic reasons, considering volunteering activity as an act of social responsibility. Helping others and giving back to society came out as the primary motive for engagement in volunteering, this supports the findings of Asting and Sax (1998), Gage and Thapa (2012), and Kironde and Klaasen (2002). All of these studies mentioned that the primary motivation behind volunteering is to serve communities and work for the good of others. Only $13.48 \%$ of the volunteers mentioned that they are volunteering for self-development, followed by $10.1 \%$ for whom volunteering was a prerequisite in their degree program and $6.7 \%$ who wanted to build connections (not only with the organizations but with the community and their peers as well). Only 1 youth volunteer mentioned reward as a motivation for volunteering, which shows that young people don't usually volunteer for reward or recognition. According to Meier and Stutzer (2008), volunteering itself is a rewarding experience as it enhances life satisfaction, and individuals who benefit more from the volunteering experience are not engaged in volunteering to get a reward or material benefit.

The survey results highlighted the variety of learning and skills learned through volunteering experience (in the field). We categorized the new learnings into three themes, i.e., soft skills, technical skills, and virtues. The majority of the volunteers $(59.5 \%)$ learned soft skills through the volunteering experience, and these soft skills include communication skills, organizational skills, teamwork, confidence, and leadership skills. These soft skills (communication, teamwork, organizational skills, confidence, leadership) are also amongst the top ten skills needed for the workplace or what employers need, according to the study conducted by Robles (2012). Another study conducted by Khasanzyanova (2017), on the soft skills acquired by the volunteers through volunteering experience, revealed that communication skills and interpersonal skills (including teamwork, responsibility, and organization) were among the soft skills learned.

Some volunteers (35\%) also highlighted that they learned empathy and compassion, which were included under the "virtues" theme in this study. Being empathic or understanding others' situation is crucial in the current global job market. Being empathetic, as an essential globalized job market skill, is mentioned by Keow Ngang (2011) under ethics, moral and professional skills, and also by Robles (2012) under interpersonal skills. Only 4 volunteers stated that they learned technical skills, including grant writing, computer and software operation, and first-aid procedures. Although very few volunteers mentioned that they learned technical skills, they are increasingly being demanded in the current job market, especially after the recent pandemic (COVID-19), where skills like computer and software operation are becoming not only preferable but essential to retain a job. This study highlights that volunteering develops more soft skills and virtues than technical skills (which are also taught through the formal education system).

Most of the young people who were mobilized after induction training via NPOs managed to volunteer in the field, and out of these volunteers, only $36 \%$ stated that they faced some difficulties while volunteering. The intrinsic motivation for volunteering, for many volunteers, was to make a difference/impact in the society, but some volunteers indicated that they did not feel that they were making a difference while they were volunteering. Unclear role descriptions of volunteers or ambiguity in the purpose of their work led to a lack of recognition and demotivation.

Transportation and cultural barriers were only identified by the female volunteers as prominent challenges they faced while volunteering. Pakistan is confronted with transportation problems because of bad planning, corruption, and lack of governance (Masood et al., 2011). According to International Labor Organization (2012), public transport is not convenient for the women in Pakistan because of the limited space, verbal and physical harassment by staff, and other male passengers and higher fare rate than male passengers. The harassment and inappropriate behaviors in public spaces obstruct women's freedom of mobility in Pakistan (ILO, 2012). Due to patriarchal norms associated with culture, women in Pakistan are limited to the domestic arena, whereas men enjoy a preferable environment to seek employment (Roomi \& Parrott, 2008). Therefore, female volunteers mentioned cultural barriers associated with orthodox thinking and gender discrimination (gender roles). According to Roomi and Parrott (2008), women's situation related to occupational roles, across Pakistan, is determined by the patriarchal forces. Transportation issues and cultural barriers are linked, and these are the 
more significant challenges linked to the country's infrastructure and culture, but some measures can be taken, specific to volunteers' engagement, to deal with these challenges. It was inspiring to see that despite facing gender-specific challenges, female participation in the volunteering programs was higher.

\section{Conclusion and Recommendations}

Young people are an asset to Pakistan, and they can play a vital role in the country's social and economic development. Non-formal education to promote volunteering activity in Pakistan can endorse the professional and social integration of young people by preparing them with the contemporary skills for the labor market. In light of the current research, it can be concluded that non-formal education plays a significant role in ensuring young people's engagement in volunteering activity. Young people can learn different soft skills, technical skills, and virtues via volunteering activity. Based on the results of the current research, the following recommendations are made, which can be taken in to account to promote youth volunteerism through non-formal education initiatives via Pakistan's youth policy and other initiatives/projects:

- Given that $83 \%$ of the volunteers reported that they learned new skills during volunteering, and most young people volunteered in the field after getting the training, induction, and opportunity. Structured programs can be introduced (focusing on training, induction, and mobility of young people) to promote youth volunteerism;

- To create volunteering opportunities for young people and ensure their mobility, it is vital to partner with the different organizations working in the field (where young people will volunteer), not only NGOs and NPOs but also the local government organizations and private sector organizations operating in diverse areas. Partnership with various organizations will also ensure that volunteers can select the field of volunteering based on their interest;

- While partnering with organizations working in the field, partnership agreement shall include clauses on gender sensitivity and clear explanation of volunteers' job description;

- Many young people got involved in the volunteering activity because they had the desire to help people and make an impact in the society. Therefore, they need to know and visualize the impact they are making in society and how they are helping people. To promote volunteerism among young people, ensuring their motivation, and assigning the right workload during the actual volunteering activity, it is essential to (a) highlight the impact they will be making in the society via volunteering activity during the induction training; (b) clearly explain their role description (job description) during the induction training and this shall be negotiated with the partner organization (in the field), where youth volunteers will be sent for actual volunteering activity;

- During the induction training, it is important to highlight what volunteers can learn through the volunteering activity, e.g., soft skills, virtues, and technical skills;

- Following points can be considered to deal with cultural barriers: (a) Include an aspect of gender sensitivity training in the induction training of volunteers; (b) arrangement of transportation during the training and induction, especially for female volunteers, to make it easy to engage in the non-formal component of volunteering; (c) after training, volunteers shall be mobilized to the partner field organization (where they will volunteer) which is closest to their residence;

- Advertising the non-formal education opportunities to promote volunteering, via different mediums, among young people is crucial to ensure that all young people get the equal opportunity to participate in the non-formal programs.

\section{Limitations}

The current research has provided a lot of insights into promoting youth volunteerism via non-formal education initiatives. As Pakistan's youth policy is not in place, there are no systematic and consistent non-formal education programs to encourage youth volunteering. That is why data was collected from the NPOs to analyze the existing practices. The purpose of the study was not to generalize the findings but to contextually understand the situation and make some recommendations (which may guide the youth policy and the strategies to achieve policy objectives) based on the existing practices and cultural context.

For the current study, purposeful sampling was used for identifying the NPOs for data collection; therefore, the data was collected from a limited number of NPOs. Elaboration of this study by collecting data from more NPOs or NGOs, fulfilling the same data collection criteria can further validate the findings. 


\section{References}

Anthony, S. (2014). Integrating soft skills in the curriculum without sacrificing content. Journal for Academic Excellence, 2(4), 1-57.

Arif, G. M., \& Chaudhry, N. (2008). Demographic transition and youth employment in Pakistan. The Pakistan Development Review, 27-70. https://doi.org/10.30541/v47i1pp.27-70

Astin, A. W., \& Sax, L. J. (1998). How undergraduates are affected by service participation. Service Participation, 39(3), 251.

Basharat, S. (2012, August 12). Craving for Change: Educated Youth, Perception Survey Report. Peace Education and Development Foundation.

Booth, J. E., Park, K. W., \& Glomb, T. M. (2009). Employer-supported volunteering benefits: Gift exchange among employers, employees, and volunteer organizations. Human Resource Management: Published in Cooperation with the School of Business Administration, The University of Michigan and in alliance with the Society of Human Resources Management, 48(2), 227-249. https://doi.org/10.1002/hrm.20277

Butt, M., Hu, B., \& Soomro, K. A. (2015). Volunteering activities in developing countries: A study of youth participation in Pakistan. European Journal of Business and Management, 7(13), 317-327.

Byrd, M. (1984). Personal growth aspects of peer counselor training for older adults. Educational Gerontology, 10, 369-385. https://doi.org/10.1080/0380127840100503

Casey, J. E. (2014). A personal journey of volunteerism. Canadian Psychology/Psychologie canadienne, 55(1), 34. https://doi.org/10.1037/a0035562

CEDEFOP (European Centre for the Development of Vocational Training). (2009). European guidelines for validating non-formal and informal learning. Luxembourg: Publications Office of the European Union. Retrieved from https://www.cedefop.europa.eu/files/4054_en.pdf

Cortesero, R. (2013). The valuation of competences acquired in the voluntary sector is linked to educational policies (Interviewer: J. Felkowski). Retrieved from: https://www.animafac.net/blog/benevolat-etcompetences/

Cuskelly, G., Taylor, T., Hoye, R., \& Darcy, S. (2006). Volunteer management practices and volunteer retention: A human resource management approach. Sport management review, 9(2), 163. https://doi.org/10.1016/S1441-3523(06)70023-7

Duvekot, R. C., Scanlon, G., Charraud, A., Schuur, K., Coughlan, D., Nilsen-Mohn, T., Paulusse, J., \& Klarus, R. (Eds). (2007). Managing European Diversity in Lifelong Learning-The many perspectives of the Valuation of Prior Learning in the European workplace. Nijmegen, Hogeschool Arnhem-Nijmegen. Retrieved from http://includ-ed.eu/sites/default/files/documents/managing_european_diversity_in_lifelong_learning.pdf

European Commission. (2000). A memorandum on lifelong learning: Commission staff working paper. SEC (2000) 1832. Brussels: EC.

Gage III, R. L., \& Thapa, B. (2012). Volunteer motivations and constraints among college students: Analysis of the volunteer function inventory and leisure constraints models. Nonprofit and Voluntary Sector Quarterly, 4l(3), 405-430. https://doi.org/10.1177/0899764011406738

Ghayur, S. (1989). Educated Unemployed in Pakistan: Estimates of Imbalances in Current Flows. The Pakistan Development Review, 28(4), 603-613.

Hamadache, A. (1993). Linking formal and non-formal education: Implications for teacher training. Paris: UNESCO. Retrieved from http://unesdoc.unesco.org/images/0010/001001/100125eb.pdf

Handy, F., \& Brudney, J. L. (2007). When to use volunteer labor resources? An organizational analysis for nonprofit management. Departmental Papers (SPP), 91. Retrieved from http://repository.upenn.edu/spp_papers/91

Hodgkinson, V. A., Weitzman, M. S., Noga, S. M., \& Gorski, H. A. (1992). Giving and volunteering in the United States: 1992 edition. Washington, DC: Independent Sector.

Huynh, J. Y., Metzer, J. C., \& Winefield, A. H. (2012). Engaged or connected? A perspective of the motivational pathway of the job demands-resources model in volunteers working for nonprofit organizations. VOLUNTAS: International journal of voluntary and nonprofit organizations, 23(4), 870-898. https://doi.org/10.1007/s11266-011-9233-1 
International Labor Organization Country Office, Pakistan. (2012, September 24). All aboard the women's rights bus. Retrieved May 31, 2020, from https://www.ilo.org/global/about-the-ilo/newsroom/features/WCMS_1 90051/lang--en/index.htm

International Labour Organization, ILOSTAT database. (2020) Data retrieved on March 1, 2020 https://data.worldbank.org/indicator/SL.UEM.1524.ZS?contextual=default\&end=2019\&locations=PK\&star $\mathrm{t}=2001$ \&view $=$ chart

Kamerade, D., \& Paine, A. E. (2014). Volunteering and employability: implications for policy and practice. Voluntary Sector Review, 5(2), 259. https://doi.org/10.1332/204080514X14013593888736

Keow Ngang, T. (2011). Soft skills integrated in sustainable higher education. Journal of Modern Education Review (ISSN 2155-7993), 1(2), 99-110.

Khasanzyanova, A. (2017). How volunteering helps students to develop soft skills. International Review of Education, 63(3), 363-379. https://doi.org/10.1007/s11159-017-9645-2

Kim, J., \& Morgül, K. (2017). Long-term consequences of youth volunteering: Voluntary versus involuntary service. Social Science Research, 67, 160-175. https://doi.org/10.1016/j.ssresearch.2017.05.002

Kironde, S., \& Klaasen, S. (2002). What motivates lay volunteers in high burden but resource-limited tuberculosis control programmes? Perceptions from the Northern Cape province, South Africa. The International Journal of Tuberculosis and Lung Disease, 6(2), 104-110.

Krippendorff, K. (1989). Content analysis. In E. Barnouw, G. Gerbner, W. Schramm, T. L. Worth, \& L. Gross (Eds.), International encyclopedia of communication (Vol. 1, pp. 403-407). New York, NY: Oxford University Press. Retrieved from http://repository.upenn.edu/asc_papers/226

Lee, Y. J., \& Moon, S. G. (2011). Mainstream and ethnic volunteering by Korean immigrants in the United States. Voluntas: International Journal of Voluntary and Nonprofit Organizations, 22(4), 811-830. https://doi.org/10.1007/s11266-010-9176-y

Lengrand, P. (1982). Structures de l'apprentissage dans les pays de l'Europe Occidentale. International Review of Education, 28(2), 189-207. https://doi.org/10.1007/BF00598446

Masood, M. T., Khan, A., \& Naqvi, H. A. (2011). Transportation Problems in Developing Countries Pakistan: A Case-in-Point. International Journal of Business and Management, 6(11), 256-266. https://doi.org/10.5539/ijbm.v6n11p256

McGarvey, A., Jochum, V., Davies, J., Dobbs, J., \& Hornung, L. (2019). Time well spent: A national survey on the volunteer experience. London, England: The National Council for Voluntary Organizations. Retrieved from https://www.ncvo.org.uk/images/documents/policy_and_research/volunteering/Volunteer-experience_ Full-Report.pdf

Meier, S., \& Stutzer, A. (2008). Is volunteering rewarding in itself?. Economica, 75(297), 39-59. https://doi.org/10.1111/j.1468-0335.2007.00597.x

Mesch, D. J., Rooney, P. M., Steinberg, K. S., \& Denton, B. (2006). The effects of race, gender, and marital status on giving and volunteering in Indiana. Nonprofit and Voluntary Sector Quarterly, 35(4), 565-587. https://doi.org/10.1177/0899764006288288

Musick, M. A., \& Wilson, J. (2007). Volunteers: A social profile. Bloomington: Indiana University Press.

Paadi, K. (2014). Perceptions on employability skills necessary to enhance human resource management graduates prospects of securing a relevant place in the labour market. European Scientific Journal, 129-143.

Palinkas, L. A., Horwitz, S. M., Green, C. A., Wisdom, J. P., Duan, N., \& Hoagwood, K. (2015). Purposeful sampling for qualitative data collection and analysis in mixed method implementation research. Administration and policy in mental health and mental health services research, 42(5), 533-544. https://doi.org/10.1007/s10488-013-0528-y

Peugny, C. (2011). Les jeunesses européennes, leurs difficultés et leur perception de l'avenir: une tentative de comparaison. Informations sociales, (3), 50-59. https://doi.org/10.3917/inso.165.0050

Qayyum, W., \& Siddiqui, R. (2007). Causes of youth unemployment in Pakistan [with comments]. The Pakistan Development Review, 611-621. https://doi.org/10.30541/v46i4IIpp.611-621

Robalino, D., \& Cho, Y. (2012). Labor market policies under a youth bulge. World Bank Policy Paper Series on Pakistan. 14/12. Retrieved from http://crossasia-repository.ub.uni-heidelberg.de/3580/1/Labour\%20 
Market\%20Youth\%20Pakistan.pdf

Robles, M. M. (2012). Executive perceptions of the top 10 soft skills needed in today's workplace. Business communication quarterly, 75(4), 453-465. https://doi.org/10.1177/1080569912460400

Roomi, M. A., \& Parrott, G. (2008). Barriers to development and progression of women entrepreneurs in Pakistan. The Journal of Entrepreneurship, 17(1), 59-72. https://doi.org/10.1177/097135570701700105

Sherr, M. L. (2008). Social work with volunteers. Chicago: Lyceum Books.

Singh, M. (2012). UNESCO GUIDELINES for the Recognition, Validation and Accreditation of the Outcomes of Non-formal and Informal Learning. PLA Inside Out: An International Journal on Theory, Research and Practice in Prior Learning Assessment, 1(2).

Smith, D. H., Stebbins, R. A., \& Grotz, J. (Eds.). (2017). The Palgrave handbook of volunteering, civic participation, and nonprofit associations. Springer. https://doi.org/10.1007/978-1-137-26317-9

Soomro, A.K., \& Shukui, T. (2015). Youth Development Challenges in Pakistan: Need for Youth Empowerment. Public Policy and Administration Research, 5(11), 98-102.

Srivastava, S. S., Tandon, R., Gupta, S. K., \& Dwivedi, S. K. (2003). Dimensions of Giving and Volunteering in West Bengal. Society of Participatory Research in Asia (PRIA). Retrieved from: http://ccss.jhu.edu/wp-content/uploads/downloads/2011/09/India_PRIA_WP_7_2003.pdf

Thompson, S. (2014). Rethinking community based learning. Adult Learning Australia Limited. Retrieved from: https://ala.asn.au/wp-content/uploads/2011/02/rethinking-community-based-learning_WEB.pdf

Torres, R. M. (2011). Lifelong learning: Moving beyond Education for All (EFA). In J. Yang, \& R. Valdés-Cotera (Eds.), Conceptual evolution and policy developments in lifelong learning (pp. 40-50). Hamburg: UNESCO Institute for Lifelong Learning. from http://unesdoc.unesco.org/images/0019/001920/192081E.pdf

US Department of Health and Human Services. (2005). Successful strategies for recruiting, training, and utilizing volunteers. A Guide for Faith-and Community-Based Service Providers: DHHS Publication No. (SMA), 05-4005. Retrieved from https://www.samhsa.gov/sites/default/files/volunteer_handbook.pdf

Veitch, J. A. (2013). Reflections on service to CPA. Canadian Psychology/ Psychologie Canadienne, 54, 50-54. https://doi.org/10.1037/a0031132

Walters, S., Yang, J., \& Roslander, P. (2014). Key Issues and Policy Considerations in Promoting Lifelong Learning in Selected African Countries: Ethiopia, Kenya, Namibia, Rwanda and Tanzania. UIL Publication Series on Lifelong Learning Policies and Strategies. No. 1. UNESCO Institute for Lifelong Learning. Feldbrunnenstrasse 58, 20148 Hamburg, Germany. Retrieved from https://unesdoc.unesco.org/ark:/48223/pf0000231157

Wellington, J. K. (2005). The" soft skills" of success. Vital speeches of the day, 71(20), 628-634.

Yusuf, M. (2008). Prospects of youth radicalization in Pakistan. Brookings, Analysis Paper, 14(7), 1-27. Retrieved from https://www.brookings.edu/wp-content/uploads/2016/06/10_pakistan_yusuf.pdf

Zia, S., \& Rehman, H. (2011). Engaging and Mainstreaming Youth in Development Agenda Youth Make it Happen. https://doi.org/10.2139/ssrn.2041170

\section{Copyrights}

Copyright for this article is retained by the author(s), with first publication rights granted to the journal.

This is an open-access article distributed under the terms and conditions of the Creative Commons Attribution license (http://creativecommons.org/licenses/by/4.0/). 